\title{
Analisis Perlindungan Konsumen Terkait Produk Komputer Rakitan
}

Yayan Hanapi

Ilmu Hukum, Fakultas HukumUniversitas Gorontalo

email:yayanhanapi@gmail.com

\begin{abstract}
The effectiveness of Article 25 Consumer protection law among business actors in this case the assembled computer seller shop is still not effective because apparently there are assembled computer seller stores that do not understand about the importance of after sales service. In connection with the Implementation of the Consumer Protection Law, particularly Article 25, it is necessary to socialize by the Department of Industry and Trade because of the importance of after sales service for the community as the consumer and the seller or as the producer so that Article 25 of Law Number 8 Year 1999 concerning consumer protection can implemented accordingly. The process of dispute settlement conducted by both parties both consumer and computer assembler sales shop is to take the non litigation path without going through BPSK.
\end{abstract}

Keywords: Effectiveness, Consumer Protection, Computer Assemble

\section{PENDAHULUAN}

Era Globalisasi saat ini teknologi semakin maju dari teknologi komunikasi hingga teknologi informasi, dan semua itu sudah tentu akan sangat mempengaruhi pola hidup masyarakat dari yang serba ada manual menjadi serba otomatis. Salah satu barang dari hasil perkembangan zaman ialah komputer. Melalui penggunaan komputer semua pekerjaan menjadi lebih mudah dan terorganisir lebih rapi daripada menggunakan sistem manual, sehingga hasil yang didapatkan dari pekerjaan yang dikerjakan dengan komputer lebih maksimal. Oleh karena itu hampir semua kantor dan tempat kerja lainnya serta sekolah menggunakan komputer sebagai sarana pendukung untuk menyelesaikan pekerjaan dan meningkatkan mutu dari pendidikan di sekolah mulai dari sekolah dasar, sampai dengan perguruan tinggi juga menggunakan komputer.

Perkembangan komputer ini juga memacu akan perkembangan Teknologi lainnya yaitu dalam bidang telekomunikasi dan informasi, sehingga menciptakan program baru yaitu internet. Setiap orang didunia dapat berhubungan satu sama lainnya hanya membutuhkan sambungan telepon atau satelit, munculnya internetini sudah barang tentu akan menarik minat masyarakat untuk mencoba dan mempelajari internet tersebut, tetapi tidak semua masyarakat memiliki komputer dirumah mereka bahkan yang sudah 
memiliki saja masih belum bisa memakai internet karena membutuhkan peralatan pendukung agar bisa memakai program internet.

Sudah barang tentu hal tersebut diatas akan membuka lahan bisnis bagi masyarakat yang mempunyai modal untuk membuka Warnet (Warung telepon), tetapi dalam mendirikan Warung internet ini pemodal sudah barang tentu akan membutuhkan beberapa perangkat komputer dan semua penunjangnya agar komputer mereka dapat menggunakan program internet. Dan sekali lagi komputer akan menjadi barang atau bahan dasar dari semua pekerjaan, maka dari itu permintaan akan komputer begitu meningkat pesat.

Bagi masyarakat komputer merupakan kebutuhan yang sangat penting, namun tidak semua masyarakat memilki komputer oleh karena itu banyak tempat penyewaan komputer bermunculan, baik itu menyewakan untuk pengetikan tugas-tugas.

Akibat dari banyaknya permintaan akan produk komputer, maka mendorong munculnya berbagai macam toko penjual produk komputer, dengan banyaknya toko-toko penjual produk komputer ini maka sudah barang tentu setiap toko komputer akan memberikan pelayanan-pelayanan yang berbeda-beda satu dengan yang lain, dari yang memberikan jaminan servis satu tahun bahkan sampai waktu yang lama, dan ada yang memberikan kemudahan bagi para konsumen yang ingin memiilki komputer tetapi uang mereka belum cukup sehingga dapat membeli komputer dengan cara kredit. Sehingga banyak pilihan bagi konsumen untuk memilih tempat atau toko dimana akan membeli komputer.

Penelitian ini bertujuan untuk mengetahui efektifitas pasal 25 tentang jaminan purna jual Undang-Undang Nomor 8 Tahun 1999 tentang perlindungan konsumen dalam menangulangi tindak kecurangan dalam jaminan purna jual yang dilakukan pelaku usaha penjual produk komputer rakitan.

\section{Kajian Teori}

\subsection{Teori Efektivitas}

Berdasarkan Ensiklopedi Umum Administrasi, Efektivitas berasal dari kata kerja Efektif, berarti terjadinya suatu akibat atau efek yang dikehendaki dalam perbuatan. Setiap pekerjaan yang efektif belum tentu efisien, karena mungkin hasil dicapai dengan penghamburan material, juga berupa pikiran, tenaga, waktu, maupun benda lainnya.

kata efektivitas sering diikuti dengan kata efisiensi, dimana kedua kata tersebut sangat berhubungan dengan produktivitas dari suatu tindakan atau hasil yang diinginkan.Suatu yang efektif belum tentu efisien, demikian juga sebaliknya suatu yang efisien belum tentu efektif.Dengan demikian istilah efektif adalah melakukan pekerjaan yang benar dan sesuai serta dengan cara yang tepat untuk mencapai suatu tujuan yang telah direncanakan. Sedangkan efisien adalah hasil dari usaha yang telah dicapai lebih besar dari usaha yang dilakukan.( Ibrahim ahmad, disertasi).

Dari pengertian diatas, efektivitas dapat dikatakan sebagai keberhasilan pencapaian tujuan organisasi dari 2 (dua) sudut pandang. Sudut pandang pertama, darisegi 'hasil' maka tujuan atau akibat yang dikehendaki telah tercapai. Kedua dari segi 'usaha'yang telah ditempuh atau dilaksanakan telah tercapai, sesuai dengan yang ditentukan. Dengan demikian pengertian efektivitas dapat dikatakan sebagai taraf tercapainya suatu tujuan tertentu, 
baik ditinjau dar segi hasil, maupun segi usaha yang diukur dengan mutu, jumlah serta ketepatan waktu sesuai dengan prosedur dan ukuran-ukuran tertentu sebagaimana yang telah digariskan dalam peraturan yang telahditetapkan.

Lebih lanjut Hidayat menjelaskan bahwa : "Efektivitas adalah suatu ukuran yang menyatakan seberapa jauh target (kuantitas, kualitas dan waktu) telah tercapai. Dimana makin besar presentase target yang dicapai, makin tinggi efektivitasnya". Sedangkan pengertian efektivitas menurut Schemerhon John R.,menyatakan bahwa; " Efektivitas adalah pencapaian target output yang diukur dengan cara membandingkan output anggaran atau seharusnya (OA) dengan output realisasi atau sesungguhnya $(\mathrm{OS})$, jika $(\mathrm{OA})>(\mathrm{OS})$ disebut efektif ".

Efektivitas menurut Prasetyo Budi Saksono (1984) adalah : "Efektivitas adalah seberapa besar tingkat kelekatan output yang dicapai dengan output yang diharapkan dari sejumlah input". Dari pengertian-pengertian efektivitas tersebut dapat disimpulkan bahwaefektivitas adalah suatu ukuran yang menyatakan seberapa jauh target (kuantitas,kualitas dan waktu) yang telah dicapai oleh manajemen, yang mana target tersebut sudah ditentukan terlebih dahulu. Berdasarkan hal tersebut maka untuk mencari tingkat efektivitas dapat digunakan rumus sebagai berikut: Efektivitas = Ouput Aktual/Output Target $>=1$ a. $\varnothing$ Jika output aktual berbanding output yang ditargetkan lebih besar atau sama dengan 1 (satu), maka akan tercapai efektivitas. b. $\varnothing$ Jika output aktual berbanding output yang ditargetkan kurang daripada 1 (satu), maka efektivitas tidak tercapai. Pada dasarnya pengertian efektivitas yang umum menunjukkan pada taraf tercapainya hasil, sering atau senantiasa dikaitkan dengan pengertian efisien, meskipun sebenarnya ada perbedaan diantara keduanya.

Efektivitas menekankan pada hasil yang dicapai, sedangkan efisiensi lebih melihat pada bagaimana cara mencapai hasil yang dicapai itu dengan membandingkan antara input dan outputnya. Istilah efektif (effective) dan efisien (efficient) merupakan dua istilah yang saling berkaitan dan patut dihayati dalam upaya untuk mencapai tujuan suatu organisasi. Jadi dapat dikatakan bahwa sebuah kegiatan tersebut adalah efektif apabila tujuan kegiatan itu akhirnya dapat dicapai. Tetapi bila akibat-akibat yang tidak dicari dari kegiatan mempunyai nilai yang lebih penting dibandingkan dengan hasil yang dicapai sehingga mengakibatkan ketidakpuasan,meskipun efektif kegiatan tersebut dapat dikatakan tidak efisien. Sebaliknya bila akibat yang tidak dicaricari dari kegiatan itu mempunyai nilai tidak penting atau remeh, maka kegiatan tersebut efisien.

Efektif lebih mengarah ke pencapaian sasaran. Efisien dalam menggunakan masukan (input) akan menghasilkan produktifitas yang tinggi, yang merupakan tujuan dari setiap organisasi apapun bidang kegiatannya. Hal yang paling rawan adalah apabila efisiensi selalu diartikan sebagai penghematan, karena bisa mengganggu operasi, sehingga pada gilirannya akan mempengaruhi hasil akhir, karena sasarannya tidak tercapai dan produktifitasnya akan juga tidak setinggi yang diharapkan. Penghematan sebenarnya hanya sebagian dari efisiensi. Persepsi yang tidak tepat mengenai efisiensi dengan menganggap semata-mata sebagai penghematan sama halnya dengan penghayatan yang tidak tepat mengenai Cost Reduction Program (Program Pengurangan Biaya), yang sebaliknya dipandang sebagai Cost Improvement Program (Program 
Perbaikan Biaya) yang berarti mengefektifkan biaya. Efektif dikaitkan dengan kepemimpinan (leadership) yang menentukan hal-hal apa yang harus dilakukan (what are the things to be accomplished), sedangkan efisien dikaitkan dengan manajemen, yang mengukur bagaimana sesuatu dapat dilakukan sebaik-baiknya (how can certain things be best accomplished).

Sedangkan dalam teori efektivitas yang dikemukakan Soerjono Soekanto, menyatakan bahwa Efektivitas hukum dalam tindakan atau realita hukum dapat diketahui apabila seseorangmenyatakan bahwa suatu kaidah hukum berhasil atau gagal mencapai tujuanya, maka hal itu biasanya diketahui apakah pengaruhnya berhasil mengatu rsikap tindak atau perilaku tertentu sehingga sesuai dengan tujuannya atau tidak. Efektivitas hukum artinya efektivitas hukum akan disoroti dari tujuan yang ingin dicapai, yakni efektivitas hukum.

Apabila yang dikomunikasikan tidak bias menjangkau masalah-masalah yang secara langsung dihadapi oleh sasaran komunikasi hukum maka akan dijumpai kesulitan-kesulitanHasilnya yaitu hukum tidak punya pengaruh sama sekali atau bahkan mempunyai pengaruh yang negatif. Hal itu disebabkan oleh karena kebutuhan mereka tidak dapat dipenuhi dan dipahami, sehingga mengakibatkan terjadinya frustasi, tekanan, atau bahkan konflik.

\section{METODE PENELITIAN}

\subsection{Lokasi Penelitian}

Penelitian ini akan dilaksanakan di Kota Gorontalo pada Toko-toko Penjual Produk komputer Rakitan yang ada di Kota Gorontalo. Alasannya, karena banyak tempat-tempat pendidikan dan perkantoran di kota Gorontalo sehingga kebutuhan akan komputer juga akan semakin banyak.

3.2 Populasi dan Sampel

Populasi penelitian ini adalah konsumen pengguna produk komputer rakitan dan produsen penjual produk komputer rakitan yakni 100 Orang konsumen dengan jumlah tersebut diambil 10 orang konsumen pengguna produk komputer rakitan yang ada di kota Gorontalo dan 2 orang produsen yakni toko Gorontalo Komputer Dan Toko Istana Komputer yang menjual produk komputer rakitan di Kota Gorontalo.

3.3. Jenis Penelitian

Jenis Penelitian ini adalah penelitian empiris yakni mengadakan penelitian langsung kelapangan dengan mengadakan wawancara atau tanya jawab langsung dengan produsen penjual produk komputer rakitan serta Marketing Dan Sales Managernya dan mengambil 10 orang konsumen pengguna produk komputer rakitan

3.4. Sumber Data

1. Data Primer

Berupa data empiris yang diperoleh langsung di lokasi penelitian (field research) melalui hasil wawancara(interview) dengan responden maupun dari hasil isian berupa jawaban terhadap pertanyaan yang termuat dalam kuesioner. yang temasuk dalam objek penelitian yaknikonsumen pengguna produk komputer rakitan dan produsen penjual produk komputer rakitan serta semata-mata di pergunakan untuk kepentingan ilmiah.

2. Data Sekunder 
Data sekunder adalah berupa data yang diperoleh melalui studi kepustakaan (library research) seperti buku-buku, perundang-undangan serta literatur yang berhubungan dengan judul ini.

3.5. Teknik Pengumpulan Data

a. Teknik pengumpulan data melalui wawancara yang dilakukan dengan mengajukan pertanyaan-pertanyaan, meminta keterangan-keterangan serta penjelasan-penjelasan secara lisan sehingga diperoleh keterangan secara langsung dari responden yang termasuk dalam objek penelitian.

b. Teknik pengumpulan data melalui bahan-bahan bacaan seperti buku-buku maupun perundang-undangan yang erat kaitannya dengan masalah yang akan dibahas dalam penelitian.

\section{HASIL DAN PEMBASAHAN}

A. Efektifitas Pasal 25 Undang-Undang Nomor 8Tahun 1999 Tentang Perlidungan Konsumen Terhadap Pelanggaran Yang Dilakukan Oleh Pelaku Usaha Produk Komputer rakitan.

Meskipun komputer rakitan bukan dibuat oleh pabrik tetapi merupakan suatu barang yang diproduksi oleh toko komputer dalam hal ini bisa disebut sebagai pelaku usaha, sehingga komputer rakitan wajib mempunyai layanan purna jual yang diberikan oleh toko komputer penjual komputer rakitan tersebut. Hal tersebut dijelaskan dalam pasal 25 ayat 1 Undang-Undang Nomor 8 Tahun 1999 "Pelaku Usaha yang memproduksi barang yang pemanfaatannya berkelanjutan dalam batas waktu sekurang-kurangnya 1 (Satu) tahun wajib menyediakan suku cadang dan/atau fasilitas purna jual dan wajib $m$ emenuhi jaminan atau garansi sesuai dengan yang diperjanjikan". Pelayanan Purna jual adalah pelayanan yan diberikan oleh pelaku usaha kepada konsumen terhadap barang atau jasa yang dijual dalam hal jaminan mutu, daya tahan, kehandalan operasional sekurang-kurangnya selama 1 (satu) tahun, seperti yang tertera pada bab I pasal 1 angka 12 Keputusan Menteri Perdagangan dan Perindustrian Republik Indonesia No. 634/MPR/Kep/9/2002 tentang Ketentuan dan Tata Cara Pengawasan Barang Dan Atau Jasa Yang Beredar Di Pasar.

Tabel 1

Pemahamanan Konsumen Komputer Rakitan Terhadap Pentingnya Layanan Purna Jual

\begin{tabular}{|l|l|l|l|}
\hline No & \multicolumn{1}{|c|}{ Jawaban Responden } & \multicolumn{1}{|c|}{ F } & \multicolumn{1}{|c|}{$\begin{array}{c}\text { Persentase } \\
(\%)\end{array}$} \\
\hline 1 & $\begin{array}{l}\text { Layanan Purna jual Dan Keberadaan } \\
\text { Kartu Garansi }\end{array}$ & 79 & 79 \\
\hline 2 & Hanya Menanyakan Kartu Garansi & 9 & 9 \\
\hline 3 & $\begin{array}{l}\text { Tidak Menanyakan Kartu Garansi Dan } \\
\text { Layanan Purna Jual }\end{array}$ & 12 & 12 \\
\hline \multicolumn{2}{|l}{ Jumlah } & 100 & 100 \\
\hline
\end{tabular}

Data dari hasil wawancara dan quisoner responden Tahun 2014

Tabel 1 tersebut diatas menunjukan bahwa tidak semua konsumen mengerti atas pentingnya layanan purna jual bagi produk komputer rakitan yang mereka beli. Apabila diperhatikan Tabel 1 tersebut, tergambar dari 100 responden, 79\% menyatakan bahwa mereka menanyakan tentang layana purna jual dan garansi atas produk komputer rakitan yang mereka beli agar sesuai 
dengan peraturan yang berlaku sedangkan 9\% menyatakan hanya menanyakan garansi atas komputer rakitan yang dibeli tanpa mengetahui berapa minimal berapa jangka waktu garansi yang sesuai dengan peraturan yang ditetapkan oleh pemerintah dan $12 \%$ meyatakan mereka tak menanyakan garansi serta bagaimana layanan purna jual tas komputer rakitan yang telah mereka beli itu.

Seharusnya konsumen mengetahui mengenai isi dari layanan purna jual serta berapa lama garansi yang diberikan oleh toko penjual produk komputer rakitan, karena dalam layanan purna jual dalam hal ini jaminan mutu (Garansi) tersebut memuat hak dan kewajiban dari konsumen dan penjual. Misalnya memuat sanksi atau akibat yang diterima oleh konsumen bila tidak melakukan apa yang tertera dalam garansi yang diberikan oleh penjual toko produk komputer rakitan, dikarenakan garansi atau jaminan mutu yang diberikan oleh toko penjual komputer rakitan kepada konsumennya dibuat untuk menguntungkan toko itu sendiri.

Tabel 2

Pemahamanan KonsumenTentang Lamanya Jaminan atau Garansi Pada Komputer Rakitan

\begin{tabular}{|c|c|c|c|}
\hline No & Jawaban Responden & F & $\begin{array}{c}\text { Persentase } \\
(\%)\end{array}$ \\
\hline 1 & Garansi Minimal 1 Tahun/Lebih & 17 & 17 \\
2 & Garansi 3 Bulan Hingga 6 Bulan & 79 & 79 \\
3 & Tidak Tahu Adanya Garansi & 4 & 4 \\
\hline \multicolumn{2}{|c|}{ Jumlah } & 100 & 100 \\
\hline
\end{tabular}

Data dari hasil wawancara dan quisoner responden Tahun 2014

Tabel 2 diatas tersebut menunjukan bahwa pengetahuan konsumen tentang lamanya jaminan atau garansi yang wajib diberikan kepada komputer rakitan baru yang telah dibeli olehkonsumen tersebut. Sebanyak $17 \%$ responden mengetahui dan mengerti berapa minimal lamanya garansi yang diberikan, sedangkan $79 \%$ responden tahu akan batas waktu jaminan atau garansi tetapi lama waktunya salah dan $4 \%$ responden tidak tahu sama sekali berapa batas waktu garansi atas produk kmputer rakitan yang dibelinya.

Pengetahuanakan berapa minimal lamanya garansi pada komuter rakitan sangat penting bagi konsumen hal ini dikarenakan banyak produsen atau toko penjual komputer rakitan memberikan garansi atas pembelian komputer rakitan selama 6 bulan dan penggantian baru "Repalace"selama 1 minggu, sudah barang tentu hal ini akan merugikan bagi konsumen produk komputer rakitan itu sendiri.

Pada kenyataannya tidak semua perangkat keras yang diinginkan oleh konsumen untuk melengkapi komputer rakitannya memiliki kartu garansi, hal ini jaran sekali mendapat tanggapan dari konsumen, dikarenakan mereka berpendapat bahwa kartu garansi atas perangkat keras itu tidak penting dan mereka hanya mementingkan garansi dari toko penjual produk komputer rakitan dimana si konsumen tersebut membeli, dapat dilihat pada tabel 3 berapa presentase konsumen yang memperdulikan pentingnya adanya kartu garansi pada setiap perangkat keras yang ada pada omuter rakitan mereka. 
Tabel 3

Kepedulian Konsumen Atas Penyertaan Kartu Garansi Pada Perangkat Keras Komputer Rakitan

\begin{tabular}{|c|l|c|c|}
\hline No & \multicolumn{1}{|c|}{ Jawaban Responden } & F & $\begin{array}{c}\text { Persentase } \\
(\%)\end{array}$ \\
\hline 1 & $\begin{array}{l}\text { Menanyakan akan adanya Kartu } \\
\text { Garansi Atas Perangkat Keras Yang } \\
\text { ada Pada Komputer Rakitan Yang } \\
\text { Telah Dibeli Tetapi Tidak Pernah } \\
\text { Mengerti Tetak }\end{array}$ & 81 & 15 \\
$\begin{array}{l}\text { Menanyakan } \\
\text { Tidak Tahu Sama Sekali }\end{array}$ & 4 & 81 \\
\hline \multicolumn{1}{|l|}{ Jumlah } & 100 & 100 \\
\hline
\end{tabular}

Data dari hasil wawancara dan quisoner responden Tahun 2014

Tabel 3 diatas tersebut menunjukan bahwa kepedulian konsumen akan adanya kartu garansi pada setiap perangkat keras yang terdapa pada komputer rakitan yang telah dibelinya. Sebanyak $15 \%$ responden yang menanyakan adanya kartu garansi atas perangkat-perangkat keras yang terpasang pada komputer rakitan mereka, sedangkan 81 \% konsumen tidak memperdulikan akan pentinggya kartu garansi pada perangkat keras yang terpasang pada komputer rakitan. Kartu garansi pada setiap perangkat keras yang terapsang pada setiap komputer rakitan menunjukan bahwa perangkat keras itu benarbenar baru dan bukan bekas dipakai beberapa bulan, selain itu keuntungan lainnya jika ada kartu garansi ialah jika pada suatu saat toko tempat konsumen membeli komputer rakitan tersebut bangkrut atau "gulung tikar", maka konsumen dapat membawa perangkat keras yang rusak kepada distributor dari perangkat keras tersebut atau langsung kepada service center khusus yang memperbaiki merekyang sama dengan perangkat keras yang rusak itu.

Ketentuan dalam Keputusan Menteri Perindustrian Dan Perdagangan Republik Indonesia No. 547/MPP/Kep/7/2002 menjelaskan bahwa barang teknlogi informasi yang beredar di pasaran wajib dilengakapi dengan kartu jaminan atau garansi seperti yang diatur dalam pasal 6 ayat 1 dan pasal 3 menjelaskan tentang lama berlakunya garansi tersebut yaitu mimal 1 tahun. Tetapi pada Keputusan Menteri ini masih dibatasi pada perangkat keras yaitu pada monitor dan printer saja. Jadi disini konsumen berhak untuk menanyakan tentang ada dan tidaknya kartu garansi pada monitor komputer atau printer yang telah dibelinya.

Dalam hal ini pada konsumen pada saat menuliskan perangkat keras yang akan dirakit kepada toko komputer haruslah menanyakan apakah semua ini masih akan ada atau masih porduksi dalam jangka waktu lama sehingga jika terjadi kerusakan atau salah satu perangkat kerasnya akan segera dapat diperbaharui atau diganti dengan yang baru tanpa menunggu waktu lama atau menghindari hal teburuk yaitu komputer rakitan itu tidak dapat dipergunakan lagi karena suku cadang perangkat kerasnya sudah tidak diproduksi lagi oleh pabriknya.

Pada saat toko penjual komputer rakitan bentuk layanan purna jual yang diberikan kepada konsumen banyak memiliki perbedaan antara toko yang satu dengan yang lain meskipun ada persamaannyaitu mungkin hanya beberapa, 
berikut ini hasil dari penelitian yang dilakukan terhadap dua buah toko penjual komputer rakitan yang mempunyai omzet yang besar dalam penjualan komputer rakitan.

1. Bentuk layanan Purna Jual Pada Toko Komputer "Gorontalo Komputer"

Sebagai produsen atau toko penjual komputer rakitan Gorontalo Komputer melakukan pemberian layanan purna jual kepada konsumennya yang membeli komputer rakitan di toko tersebut. Bentuk layanan purna jualnya ada tiga macam yaitu garansi toko dan kartu garansi dari setiap perangkat keras yang dipakai dalam komputer rakitan tersebut, penyediaan suku cadang bagi komputer rakitan dan pelayanan perbaikan atau service.

\section{a. Pemberian Garansi}

Setiap pembelian komputer rakitan yang baru oleh konsumen, toko Gorontalo Komputer akan memberikan jaminan garansi toko yang berupa segel toko yang ditempel pada setiap perangkat keras yang ada. Disegel toko tersebut tertulis nama toko, tanggal, bulan dan tahun pembelian serta segel juga dipasang pada CPU untuk menghindari komputer dibuka oleh pihak lain dan hal ini dlakukan agar garansi tetap berlaku dikarenakan jika segel CPU dibuka maka tanggung jawab pihak Gorontalo Komputer terhadap jaminan atas komputer rakitan itu akan hangus, sehingga jaminan garansinya tersisa pada kartu jaminan atas perangkat kerasnya yang diberikan oleh pabrik pembuatnya.

Berdasarkan wawancara dengan Jefri selaku marketing \& Sales Manager Gorontalo Komputer (wawancara tanggal 27februari 2014) mengatakan bahwa Komputer Rakitan Pada setiap perangkat keras yag diminta oleh konsumen untuk melengkapi komputer rakitan tidak semua memiliki kartu garansi, karena hal ini biasanya tawaran dari distributor utama dalam hal pemotongan harga setiap produk yang akan dibeli pihak toko komputer rakitan pada umumnya dan Gorontalo Komputer pada khususnya 2 \$ hingga 5 \$ (dollar Amerika), dan potongan ini ditambah lagi dengan potongan harga pembelian dalam jumlah besar. Hal ini sudah barang tentu akan membuat pedagang manapun akan tergiur untuk mendapatkan potongan harga sebanyak itu, hal inilah yang menyebabkan ada beberapa atau hampir semua perangkat keras yang dijual tidak ada kartu garansi seperti yang diatur oleh pemerintah.

Selain kartu garansi dari pabrik Gorontalo Komputer juga akan memberikan $\mathrm{CD}$ program yang berasal dari setiap perangkat keras yang dibeli oleh konsumen. CD ini sangtlah penting dikarenakan tanpa CD ini maka perangkat keras yang beli tidak akan dapat digunakan tanpa ada CD tersebut. Sehingga sering pihak toko memperingatkan kepada konsumen untuk menyimpan baikbaik CD program itu. Karena jika suatu saat ingin menginstal ulang kompuer rakitan itu maka semua $\mathrm{CD}$ perangkat keras harus digunakan agar dapat diaplikasikan pada prgram baru yang akan dinstal.

Lebih lanjut dikatakan oleh Jefri selaku marketing \& Sales Manager Gorontalo Komputer (wawancara tanggal 28 februari 2014) yakni Garansi toko selama 1 (satu) tahun tersebut ditambh lagi dengan garansi repalace selama 3 bulan yaitu jika dalam jangka waktu 3 bulan itu komputer mengalami kerusakan ringan atau berat maka pihak toko akan mengganti komputer rakitan dengan yang baru. Tetapi hal ini pada setiap toko komputer di Kota Gorontalo pelayanan ini dilihat dari penggunaanya misalnya Korporasi, home User dan kalangan Mahasiswa. Kebanyakan jaminan garansi pada setiap toko sering dipakai untuk para pemakai ditingkat Korporasi karena mereka pemakai 
terbesar serta menguntungkan dan untuk pemakai skala kecil seperti Home User dan kalangan Mahasiswa jarang bahkan tidak pernah diberlakukan jaminan garansi toko.

Disini pihak toko yaitu Gorontalo Komputer pada saat memberikan jaminan garansi toko akan berusaha memenuhinya dengan semaksimal mungkin dan meminta kepada konsumen untk jujur terhadap penyebab kerusakan yang menimpa komputer rakitan mereka, sehingga pihak Gorontalo komputerakan mencoba memperbaikinya meskipun itu akibat hubungan arus pendek tetap akan dilakukan perbaikan maka konsumen harus membei perangkat keras yang baru uuntuk menggantikan yang rusak tersebut.

b. Penyediaan Suku Cadang Untuk Perangkat Keras Komputer Rakitan.

Menurut wawancara dengan Jefri selaku marketing \& Sales Manager Gorontalo Komputer (wawancara tanggal 29 Februari 2014) mengatakan Selain memberikan garansi toko Gorontalo Komputer juga memberikan pelayanan peyediaan suku cadang bagi seluruh bagian komputer rakitan yang telah dibeli oleh konsumen, tetapi toko Gorontalo Komputer tidak bisa secara langsung menyediakan barang tersebut, minimal membutuhkan waktu 1 hari hingga 3 hari hal ini dikarenakan proses pemesanan barang yang diminta oleh setiap konsumen selalu langsung diambilkan ke pabrik atau distributor utamanya sehingga kami menjamin bahwa setiap barang yang dijual di toko gorontalo komputer adalah baru dan bukan barang bekas pakai, semua masih ada segel pada kotak pembukusnya bukan sudah terbuka seperti pada toko komputer lain, karena hampir semua toko komputer memasang display pada estalase tokonya dan semua segel kotak sudah terbuka, barang itu bisa saja telah dicoba aatau bahkan telah dipakai beberapa hari karena tidak ada tanda atau bekas yang bisa membuktikannya.

Oleh karena itu kami selalu menginformasikan kepada konsumen tentang proses penyediaan suku cadang di gorontalo komputer dan hal kenapa kami disini tidak mau memasag diplay suku cadang perangkat keras pada etalase toko kami karena kami tidak menstock barang karena kami tidak tau apa yang diinginkan konsumen, selain itu kami juga menghindari kerugiaan jikalau nanti kami menstock barang dan kemudian barang tersebut tidak laku. Di gorontalo komputer kami selalu melayani pembeliaan suku cadang sekecil apapun kecuali jika barnag dipesan tersebut sudah tidak diproduksi lagi maka kami tidak dapat memenuhinya tetapi kami akan memberikan alternatif lain yang mungkin bisa menggantikan suku cadang yang dicari.

c. Perawatan Atau Service Pada Komputer Rakitan.

Dalam perawatan atau service toko Gorontalo Komputer melakukannya dalam dua tahap yaitu memperbaiki ditempat konsumen dan meperbaiki di gorontalo komputer. Memperbaiki ditempat konsumen dilakukan jika konsumen yang komputer rakitannya mengalami masalah dan tidak dapat membawa komputer tersebut ke toko Gorontalo Komputer maka kami akan mengirimkan teknisi yang akan melakukan perbaikan ditempat konsumen tetapi jika kerusakan yang dialami sangat parah maka teknisi kami akan membawa komputer ke toko untuk di lakukan perbaikan dengan secara intensif.

Perbaikan di toko Gorontalo komputer dilakukan jika konsumen langsung mengirimkan komputer yang mengalami gangguan ke toko gorontalo komputer. Di tempat kami para teknisi siap untuk memperbaikinya tetapi terlebih dahulu pihak konsumen wajib memberitahukan apa permasalahan yang dialami 
komputer rakitan tersebut dan apa penyebabnya jika konsumen itu tahu. Dalam hal ini toko Gorontalo Komputer mengharap akan kejujuran konsumen agar proses perbaikan lancar dan komputer segera baik kembali.

2. Bentuk layanan Purna Jual Pada Toko Komputer "Istana Komputer"

Layanan purna jual adalah salah satu hal penting yang harus dilakukan oleh penjual komputer rakitan demi menarik minat pembeli atau konsumen bahkan mungkin untuk melaksanakan peraturan yang telah ditetapkan oleh pemerintah.Hasil penelitian menunjukan ada tiga macam layanan purna jual yangditawarkanoleh toko penjual komputer rakitan ini yaitu : Garansi, Penyediaan suku cadang, serta jasa perawatan atau service terhadap komputer rakitan secara menyeluruh atau pada salah satu perangkat keras yag terpasang pada komputer rakitan tersebut dan bahkan pada perbaikan program (Software) yang terdapat pada komputer rakitan tersebut.

a. Pemberian Garansi

Setiap konsumen yang membeli komputer rakitan pada toko Istana Komputer akan diberi garansi atas komputer rakitan itu, dengan dua macam bentuk garansi yakni garansi pabrik dan garansi toko. Maksudnya garansi pabrik ialah adanya kartu garansi yang menyertai setiap perangkat keras yang digunakan dalam komponen komputer rakitan sertai ditandai dengan segel pabrik yang ditempelkan pada perangkat keras itu untuk menandai bahwa barang itu belum pernah dibuka oleh siapapun setelah keluar dari pabrik, sedangkan garansi toko merupakan jaminan yang diberikan oleh toko dalam hal ini Istana Komputer dalam bentuk segel yang dibuat oleh toko itu yang juga ditempelkan pada masing-masing perangkat keras tersebut diatas yang menunjukan awal tanggal, bulan dan tahun pembelian produk komputer rakitan (wawancara tanggal 28Februari 2014 dengan Luhut Ferdy Pimpinan Istana Komputer).

Menurut pernyataan Luhut "tidak semua perangkat keras yang dijualnya memiliki kartu garansi tetapi jika ada salah satu yang rusak maka perangkat keras itu akan tetap diperbaiki kepada pabrik pembuatnya", perangkat keras disini biasanya adalah hard disk, processor dan bahkan ada ada monitor yang tidak ada kartu garansinya jadi hanya ada segel pabrik dan Bard code nya saja. Garansi toko disini meliputi garansi pada toko komputer rakitan secara menyeluruh hanya untuk perangkat lunaknya (Software) atau program yang menjalankan komputer tersebut sehingga menyebabkan komputer tidak bisa digunakan dengan semestinya maka pihak toko akn memperbaikinya secra Cuma-Cuma tanpa dikenai biaya selama garansi satu tahun belum habis.

Pada perangkat kerasnya toko memberikan garansi satu minggu , maksudnya disni perangkat keras akan diganti dengan yang baru dan memilki spesifikasi sama jika dalam waktu satu minggu terjadi kerusakan pada salah satu atau seluruh perangkat keras yang terpasang, menyebabkan komputer menjadi tidak berfungsi. Tetapi setelahsatu minggu jika masih ada kerusakan maka tokotidak akan menggati dengan baru tetapi hanya melakukan perbaikan dengan mengirimkan perangkat keras tersebut kepada distributor atau Service Center selama masa satu tahun garansi pabrik belum berakhir dan hal ini juga tidak dipungut biaya.

b. Penyedian Suku Cadang Untuk Perangkat keras Komputer Rakitan

Selain pemberian garansi toko Istana Komputer juga memberikan pelayanan penyediaan suku cadang untuk seluruh bagian dari perangkat keras yang terdapat pada komputer rakitan. Suku cadang bagi perangkaat keras komputer 
rakitan ini bisa langsung didapatkan oleh konsumen sewaktu-waktu si konsumen tersebut membutuhkannya, tetapi jika barang atau suku cadang yang dicari oleh konsumen tergolong barang yang susah didapat dipasaran maka toko akan memberikan tenggang waktu 1 minggu untuk mendapatkan suku cadang yang sesuai dengan keinginan konsumen dan jika konsumen tidak bisa menunggu lama maka akan dipinjamkan suku cadang bekas yang ada hingga barang yang dipesan telah dapat, hal ini dilakukan demi kepuasan konsumen.

B. Upaya Penyelesaian Sengketa Antara Pelaku Usaha Dengan Konsumen Produk Komputer Rakitan

Menurut hasil penelitian menunjukan bahwa konsumen dirugikan dalam pemberian layanan purna jual yang dilakukan oleh produsen atau toko penjual komputer rakitan, toko penjual komputer rakitan tidak memenuhi layanan purna jual seperti yang dijanjikan pada saat konsumen membeli komputer rakitan, ada beberapa konsumen dari toko penjual komputer rakitan yang merasa dirugikan dalam hal layanan garansi maupun layanan penyediaaan suku cadang dari perangkat keras yang terpasang pada komputer rakitan si konsumen. Terkait dengan masalah tersebut tindakan yang dilakukan oleh konsumen ada berbagai macam, berikut data dari responden :

Tabel 4

Tindakan Yang Dilakukan Konsumen Dalam Penyelesaian Sengketa Dengan Toko Penjual Komputer Rakitan

\begin{tabular}{|c|c|c|c|}
\hline No & Jawaban Responden & $\mathrm{F}$ & $\begin{array}{c}\text { Persentase } \\
(\%)\end{array}$ \\
\hline 1 & Tidak melakukan tindakan apapun & 73 & 73 \\
\hline 2 & Jalur non Litigasi tanpa melalui BPSK & 27 & 27 \\
\hline 3 & Jalur Non Litigasi melalui BPSK & 0 & 0 \\
\hline 4 & Jalur Litigasi & 0 & 0 \\
\hline & Jumlah & 100 & 100 \\
\hline
\end{tabular}

Data dari hasil wawancara dan quisoner responden Tahun 2014

Tabel 4 diatas tersebut menunjukan bahwa tidak ada konsumen yang melakukan upaya penyelesaian sengketa melalui jalur Non Litigasi maupun jalur Litigasi, hal ini disebabkan karena menurut konsumen biaya yang dikeluarkan untuk melakukan proses penyelesaian sengketa melalui jalur litigasi lebih besar dari pada kerugian yang diderita, sehingga hampir sebagian besar konsumen yaitu $73 \%$ responden yang merupakan konsumen tidak melakukan tindakan apapun pada saat dirinya dirugikan dalam hal pelayanan purna jual, sedangkan $27 \%$ konsumen yang menjadi respondenmengambil jalur Non Litigasi tanpa melalui BPSK untuk menyelesaikan sengketa dengan toko penjual toko komputer rakitan disini bentuknya ialah perdamaian dengan cara pemberian ganti rugi dari toko penjual komputer rakitan kepada pihak konsumen.

Hambatan pada proses penyelesaian sengketa diluar pengadilan (Non Litigasi) ialah jika pada saat proses peradilan berlangsung atau pada saat pertama dan salah satu pihak merasa dirugikan (Produsen), dengan proses Non Litigasi ini maka pada sidang selanjutnya pihak tersebut tidak akan hadir bahkan seterusnya setelah dilakukan pemanggilan yang sesuai dengan proses penyelesaian diluar pengadilan (Non Litigasi), sehinggga proses Non Ltigasi berhenti karena tidak dapat dilanjutkan kembali karena tidak hadirnya pihak 
produsen yang telah dipanggil oleh pihak BPSK meskipun peraturannya jika salah satu pihak dalam hal ini produsen yang tidak hadir pada sidang kedua maka gugatan konsumen dikabulkan, tetapi jika proses Non Litigasi ini memilih cara mediasi dan konsiliasi maka keputusannya tidak berlaku karena salah satu pihak tidak menanda tanganinya. Sehingga jika ingin mencari keadilan maka dapat meneruskan kasusnya kepengadilan atau proses litigasi.

1. Upaya Penyelesaian Sengketa Diluar Pengadilan (Non Litigasi)

Konsumen sebenarnya bisa melakukan upaya penyelesaian sengketa melalui jalur Non Litigasi. Hal ini diatur dalam UUPK pada pasal 45 ayat 2 yang mengatakan "Penyelesaian Sengketa Konsumen Dapat ditempuh Melalui Pengadilan atau Diluar pengadilan berdasarkan Pilihan Sukarela Para Pihak Yang Bersengketa", pada pasal 45 ayat 4 mengatakan "jika telah memilih upaya penyelesaian sengketa diluar pengadilan, gugatan pengadilan juga dapat ditempuh jika upaya itu dinyatakan tidak berhasil oleh satu pihak atau pihak yang bersengketa", hal ini berarti upaya penyelesaian sengketa melalui pengadilan pun masih tetap terbuka apabila para pihak gagal menyelesaiakan sengketa diluar pengadilan. Jadi penyelesaian sengketa konsumen diluar pengadilan dilakukan untuk mencapai kesepakatan mengenai bentuk dan besarnya ganti rugi atau mengenai tindakan tertentu untuk menjamin tidak akan terulang kembali kerugian yang diderita oleh konsumen.

Untuk penyelesaian sengketa konsumen diluar pengadilan pemerintah telah membentuk suatu badan khusus yaitu BPSK (Badan Penyelesaian Sengketa Knsumen), yang diatur dalam pasal 49 UUPK. Jadi disini konsumen dan toko penjual komputer rakitan diberikan kesempatan untuk menyelesaiakan masalah yang ada dengan bantuan BPSK maka akan menghemat waktu dan biaya dikarenakan keputusan yang dikeluarkan bersifat terakhir dan mengikat sehingga tidak ada upaya hukum lagi.

2. Upaya Penyelesaian Sengketa Peradilan Umum (Litigasi)

Konsumen yang telah dirugikan bisa mengajukan tuntutan ke peradilan umum. Hal ini dilakukan jika penyelesaian melalui non litigasi tidak berhasil untuk menyelesaiakan sengketa yang terjadi antara konsumen dengan toko penjual komputer rakitan. Penyelesaian lewat pengadilan bisa dilakukan secara perorangan maupun secara berkelompok seperti Small Claim, Legal Stading Dan Class Action.

Pada proses penuntutan oleh konsumen harus memperhatikan pokok masalahnya, maksudnya disini pada proses jual beli tersebut. Misalnya seorang konsumen yang tidak mendapat kartu garansi pabrik atas monitor yang telah dibelinya dan kemudian ia meminta kepada toko penjual untuk menyerahkan kartu garansi yang belum diterima oleh konsumen, tetapi toko tersebut berdalih bahwa untuk pada bulan pembelian yang dilakukan oleh konsumen kartu garansi telah ditiadakan, padahal dalam pembelian bulan itu diadakan undian berhadiah dengan mengirmkan kartu garansi dari pembelian monitor tersebut. Sudah jelas dalam hal ini toko penjual komputer rakitan telah melakukan tipu muslihat dan dapat dituntut.

Sedangkan penyelesaian sengketa secara berkelompok dilakukan untuk dapat megurangi biaya penyelesaian perkara misalnya pada small claim, hal ini dilakukan oleh sekelompok konsumen yang telah dirugikan atas pelayanan purna jual yang telah dilakukan oleh toko penjual komputer rakitan, didalam small claim ini alasan utama diiznkan dalam perkara konsumen adalah kepentingan dari pihak penggugat tidak dapat diukur semata-mata dari nilai 
uang kerugiannya, keyakinan konsumen bahwa pintu keadilan seharusnya terbuka bagi siapa saja termasuk konsumen kecil, selain itu small claim ini digunakan untuk menjaga integritas badan peradilan. Dalam UUPK yang dapat mewakili konsumen dalam melakukan gugatan kepengadilan adalah kelompok konsumen atau lembaga swadaya masyarakat (LPKSM).

Proses legal standing ini biasanya dilakukan oleh lembaga konsumen yang mempunyai hak legal standing. Dimana telah diakui oleh pemerintah dan telah terdaftar, sperti yang diatur dalam pasal 46 ayat 1 huruf (c) UUPK. Legal Standing ini lebih jelasnya terdapat didalam Undang-Undang Nomor 23 Tahun 1997 tentang pengelolaan lingkungan hidup. Dalam UUPK sendiri legal standing tidak diatur secara rinci, tetapi hal ini bukan berati dalam perkara konsumen tidak dapat diajukan dalam perkara legal standing kepengadilan. Didalam Legal Standing tuntutan ganti kerugian uang tidak diperkenankan, karena itu jika konsumen akan menuntut dengan ganti kerugian uang lebih baik tidak menggunakan legal standing. Karena tiuntutan ini dilakukan oleh LPKSM dimana tidak mengalami kerugian secara langsung. Selain itu pihak dalam hal ini pemerintah dapat juga melakukan tuntutan namun hal ini baru terjadi apabila kerugian yang terjadi sangat besar.

\section{KESIMPULAN DAN SARAN}

A. Kesimpulan

Efektifitas Pasal 25 Undang-undang perlindungan konsumen dikalangan pelaku usaha dalam hal ini toko penjual komputer rakitan masih belum efektif karena ternyata masih ada toko penjual komputer rakitan yang tidak mengerti tentang pentingnya layanan purna jual.

B. Saran

Berkaitan dengan Implementasi Undang-Undang Perlindungan Konsumen khususnya pasal 25 maka perlu dilakukan sosialisasi oleh Dinas Perindustrian dan Perdagangan karena mengingat pentingnnya layanan purna jual bagi masyarakat sebagai konsumen dan pihak penjual atau sebagai produsen agar pasal 25 undang-undang Nomor 8 Tahun 1999 tentang perlindungan konsumen dapat dilaksanakan sesuai dengan semestinya.

\section{REFERENSI}

Buku

Ari, Purwadi, 2000, Pengaturan Persoalan Perlndungan Konsumen Dalam UUPK, Angkasa. Bandung

AZ. Nasution, 1995, Konsumen dan Hukum, Tinjauan Sosial dan Hukum Pada Perlindungan Konsumen Indonesia, Pustaka Sinar Harapan : Jakarta. Daya Widya : Jakarta.

Bayu, Iswahyudi, 2003, Tanggung Gugat Terhadap Produk Yang Berkaitan dengan Penyalahgunaan Keadaan, Mandar. Bandung

Bambang Suggono, 2005, Metode Penelitian Hukum, cetakan ke-7, RajaGrafindo Persada, Jakarta.

Bambang Waluyo, 1991, Penelitian Hukum dalam Praktek, Sinar grafika,Jakarta.

Celina Tri Siwi Kristiyanti, 2008, Hukum Perlindungan Konsumen, Sinar Grafika : Jakarta. 
Creswell, Jhon W, 2002. Research Design Qualitative \& Quantitative Approach.Editor: Crysnanda DL, KIK Press, Jakarta.

Darji Darmodiharjo, 2006 , Pokok-Pokok Filsafat Hukum, PT Gramedia Pustaka Utama, Jakarta

Darus, Mariam, 1990, Perlindungan Terhadap Konsumen Di Tinjau Dari Segi Kontrak (Baku), Makalah Pada Symposium Aspek-Aspek Hukum Perlindungan Konsumen, BPHN-BINA Cipta, Jakarta

Gunawan Widjaja dan Ahmad Yani, 2000, Hukum Tentang Perlindungan Konsumen, PT Gramedia Pustaka Utama, Jakarta.

Jhon Pieres, 2007, Layanan Purna Jual, Pelangi Cendekia : Jakarta.

Jogiyanto H.M, 1989, Pengenalan Komputer, Edisi ke-1, Cetakan ke-1, Andi offset, Yogyakarta.

2004. Metode Penelitian Bisnis : Salah Kaprah dan Pengalaman- Pengalaman. BPFE. Yogyakarta.

Johanes Gunawan, 2008, Product Liability Dalam Hukum Bisnis Di Indonesia, Angkasa : Bandung.

Lili Rasjidi dan I.B Wysa Putra, 1993, Hukum Sebagai Suatu Sistem, Remaja Rusdakarya, Bandung

Maria S.W. Sumardjono, 2001, Transitional Justice atas "Hak Sumber Daya Alam”, dalam Komisi Nasional Hak Asasi Manusia: Keadilan dalam Masa Transisi, Komisi Nasional Hak Asasi Manusia, Jakarta

Marwan Mas, 2004,Pengantar Imu Hukum, Ghalia Indonesia, Bogor

Miru, Ahmadi dan Sutarman Yodo, 2004, Hukum Perlindungan Konsumen .Raja Grafindo Persada, Jakarta

Moeljatno, 1996, Kitab Undang-Undang Hukum Perdata, Bumi Aksara : Jakarta.

Nasution, AZ. 1995, Konsumen Dan Hukum : Tinjauan Sosial, Ekonomi dan Hukum pada Perlindungan Konsumen Indonesia, Pustaka Sinar Harapan, Jakarta

1994, iklan dan konsumen( tinjauan dari segi hukum dan perlindungan konsumen) Dalam Manjemen Dan Usahawan Indonesia, Nomor 3 Thn. XXIII, LPM FE-UI, Jakarta

,2001, Hukum Perlindungan Konsumen, Diadit Media,Tarawang Press, Yogyakarta

Philipus M. Hadjon, 1987, perlindungan hukum Bagi Rakyat Indonesi, PT. Bina Ilmu, Surabaya

Robert H. Blissmer, 1985,Computer Annual, An Introduction To Information System, New York

Ronny Hanitijo Soemitro, 1988, Metodologi Penelitian Hukum, cetakan ke-3, Ghalia Indonesia, Jakarta

Satjipto Raharjo, 2010, Penegakan Hukum Progresif, PT Kompas Media Nusantara, Bandung.

Satrio, J. 1992, Hukum Perjanjian ( Perjanjian Pada Umumnya) ,Citra Aditya Bakti, Bandung.

Samsul, Inosentius, 2004, Perlindungan konsumen Kemungkinan Tanggung Jawab Mutak,Rineke Cipta, Jakarta.

Shidarta, 2000, Hukum Perlindungan Konsumen Indonesia, Grasindo, Jakarta

Sufirman Rachman, 2008. Pengetahuan Dasar Dalam Beracara Perdata. Umitoha Ukhuwah Grafika, Makasar 
Suhariningsih, 2009, Asas dan Pembaharuan konsep Menuju Penertiban, Prestasi Pustaka Publisher, Jakarta

Sunaryati Hartono, 1991 Politik Hukum Menuju Satu Sistem Hukum Nasional,Alumni, Bandung.

Shidarta, 2000, Hukum Perlindungan Konsumen Indonesia, Grasindo : Jakarta.

Shofie, Yusuf, 2003 , Perlindungan Konsumen dan Instrumen-Instrumen Hukumnya, Citra Aditya Bakti, Bandung.

-----------, 2003, Penyelesaian Sengketa Konsumen Menurut UUPK Teori Dan Praktek Penegakan Hukum, Citra Aditya Bakti : Bandung.

Sidabalok, Janus Sidabalok, 2006, Perlindungan Konsumen Di Indonesia, Pt. Citra Aditya Bakti, Bandung

Sudikno Mertokusumo. 1999. Mengenal Hukum : Suatu Pengantar. Liberty. Yogyakarta.

Sutan Remi, 2008, Kartu Jaminan atau Garansi bagi Produk Elektronik, Rineke Cipta : Jakarta.

Syahruddin Nawi, 2013, Penelitian Hukum Normative Versus Penelitian Hukum Empiris, Umithoha Ukhuwah Grafika, Makassar.

Syamsudin Pasamai, 2010, Metodologi Penelitian dan Penulisa Karya Ilmiah Hukum, Umithoha Ukhuwah Grafika, Makassar.

A. Peraturan Perundang-Undangan

Undang-Undang Republik Indonesia No. 8 Tahun 1999 Tentang perlindungan Konsumen.

Keputusan Menteri Perindustrian Dan Perdagangan Republik Indonesia No. $547 / \mathrm{MPP} / \mathrm{Kep} / 7 / 2002$ Tentang Pedoman Pendaftaran Petunjuk Penggunaan (Manual) Dan Kartu Jaminan Garansi Dalam Bahasa Indonesia Bagi Produk Teknologi Dan Elektronika.

Keputusan Menteri Perindustrian Dan Perdagangan Republik Indonesia no. 634/MPP/Kep/9/2002 Tentang Ketentuan Dan Tata Cara Pengawasan Barang dan atau Jasa Yang Beredar di Pasar.

B. Tesis/ Disertasi

Ahmad, Ibrahim, 2013. Judul disertasi : Analisis Hukum Penatagunaan Tanah Untuk Kepentingan Pembangunan di Provinsi Gorontalo

Roy moonti, 2013. Judul tesis : "Efektifitas Pelayanan Publik Berkenaan Dengan Pengurusan Izin Mendirikan Bangunan (IMB) Dalam Rangka Mewujudkan Good Governance (Studi di Kota Gorontalo)

C. Sumber Rujukan Dari Website

Sumarno, JPN, 2003, Pengenalan Teknologi Komputer dan manfaatnya, http://www.sejarahkomputer.html (diakses taggal 10 Desember 2013) 